Research Article

\title{
Regional Disparities and Determinants of Caesarean Deliveries in India
}

\author{
Bhawna Kathuria', Sherin Raj TP
}

${ }^{1}$ Assistant Research Officer, Department of Epidemiology, The National Institute of Health and Family Welfare, New Delhi, India. ${ }^{2}$ Assistant Research Officer, Office of the Dean, The National Institute of Health and Family Welfare, New Delhi, India.

DOI: https://doi.org/10.24321/2349.2880.202018

\section{I $\quad \mathbf{N} \quad \mathbf{F} \quad \mathbf{O}$}

\section{Corresponding Author:}

Sherin Raj TP, The National Institute of Health

and Family Welfare, New Delhi, India.

E-mail Id:

sraj@nihfw.org

\section{Orcid Id:}

https://orcid.org/0000-0002-5478-669X

How to cite this article:

Kathuria B, Sherin Raj TP. Regional Disparities and Determinants of Caesarean Deliveries in India. Ind J Youth Adol Health 2020; 7(4): 15-23.

Date of Submission: 2021-03-01

Date of Acceptance: 2021-03-29

\section{$\begin{array}{llllllll}\mathbf{A} & \mathbf{B} & \mathbf{S} & \mathbf{T} & \mathbf{R} & \mathbf{A} & \mathbf{C} & \mathbf{T}\end{array}$}

Background: The caesarean rate in India has been increased from 8.5\% (NFHS-III) during 2005-06 to 17.2\% (NFHS-IV) during 2015-16.

Objective: The main objective of the study is to assess the regional disparities and determinants of caesarean deliveries in India.

Material and Method: It is a descriptive study. The fourth round of National Family Health Survey, India (NFHS-4), conducted in 2015-16 has been analysed for the purpose of this study.

Result: The study found that the C-section deliveries are significantly higher in southern region followed by western region in India. Social factors such as higher education of mother, residing in urban area, belong to richest wealth group, mothers belong to non-SC/ST category are more likely to opt for $\mathrm{C}$-section delivery. Evidence also indicates that risk factors like high age of mother, high birth order, complicated pregnancy, multiple births, size of child at birth, weight of child at birth significantly influences the decision of C-section deliveries. Institutional and Individual Behavioural Factors such as number of ANC visit, place of delivery, access to mass media are also significant determinants of opting C-section delivery. Delivering high quality timely care and counselling measures throughout the gestation period as a measure to minimise C-section deliveries is the responsibility of every midwife healthcare provider, is an effective way. There is an urgent need to monitor the deliveries in clinics and hospitals to find out the right balance between demand and provisioning of high quality health care services.

Keywords: C-section, Regional Disparities, Caesarean Delivery, India, Risk factors

\section{Introduction}

During the last decade, the rising incidence of caesarean section (C-section or CS) has become a serious concern among the public health experts globally. In most countries, the caesarean section rate exceeded the level of 10-15\% recommended by World Health Organization (WHO). ${ }^{1}$ In
2015, WHO stated that, every effort should be made to provide C-section to women in need. ${ }^{2}$

$\mathrm{C}$-section is a lifesaving intervention for both mother and unborn child. However, unnecessary CS deliveries are harmful for health and wellbeing of both mother and child. ${ }^{3,4}$ The main reason for rising $\mathrm{CS}$ is rapid socio-economic changes, 
medicalization of women's health, altered family structure, changing role of women in the society, biological urge and good strength of children in the competitive world. ${ }^{5}$ The increasing trend of CS has generated much controversy regarding the causes of such tendency. There are possibly two general explanations to this increased C-section trend. First, it is mostly considered that overuse of health care facilities for the motive by the hospitals, leads to increased institutional deliveries. Second, it is also considered that increasing demand from women even in developing countries for $\mathrm{C}$-section to avoid pain with the increasing economic and educational advancement. ${ }^{6}$

C-section rates vary significantly between geographical settings, ranging from less than one percent in Chad to $45.9 \%$ in Brazil. ${ }^{7}$ World-wide large disparity has been observed in C-section rates, Latin America and Caribbean region reported the highest rates $(40.5 \%)$, followed by Northern America (32.3\%), Oceania (31.1\%), Europe (25\%), Asia (19.2\%) and Africa (7.3\%). ${ }^{8}$ The first large scale demographic survey, National Family Health Survey (NFHS-I), conducted in India estimated the caesarean rates as 2.9\% (1992-93) and 7.1\% at NFHS-II conducted during 1998-99. NFHS-III conducted during 2005-06 estimated increased caesarean rates of $8.5 \%$ in India which further increased to $17.2 \%$ at NFHS-IV during 2015-16. ${ }^{9}$ In the present article an attempt has been made to assess the regional disparities in $\mathrm{C}$-section deliveries and influence of various associated factors responsible for caesarean deliveries in India.

\section{Objectives}

The main objective of the study is to assess the regional disparities and determinants of C-section deliveries in India. The specific objectives of this study are:

- To examine the levels of birth by C-section and emergency $\mathrm{C}$-section in India and its regions (states/ UTs).

- To study the differentials in C-section deliveries by various factors in India and its regions.

- To find out the determinants of C-section deliveries in India.

\section{Materials and Methods}

The dataset of fourth round of National Family Health Survey (NFHS-4) India, conducted in 2015-16 has been analysed for the purpose of this study. ${ }^{9}$ The NFHS is a series of surveys providing information on population, health and nutritional status of mother and child in India and its 36 states and union territories. During the survey, 699,686 girls and women aged between 15 and 49 were interviewed and information on last three pregnancies during five years preceding the survey was collected from 540,671 ever-married women.

\section{Dependent and Independent Variables}

In the present paper, the dependent variables were C-section births and emergency C-section births from NFHS-4 data. We considered the births which were decided to deliver by C-section after onset of labour pain as emergency C-section births. The independent variables used in this study were socio-economic factors, risk factors, institutional factors and individual behavioural factors.

Binary logistic regression has been performed in which the individual effect of various associated factors on C-section births are measured. Odds ratio (OR) were employed to interpret the effects of the predictor variables for each of the outcome variable. The data has been analysed using IBM SPSS Statistics version 20.

\section{Result}

\section{Levels of C-section births and emergency C-section births}

The percentage of births delivered by C-section and emergency $\mathrm{C}$-section births in India and its regions has been shown in Figure 1. The figure shows that the percentage of births by $\mathrm{C}$-section in India is $\mathbf{1 7 . 2} \%$ and the percentage of emergency C-section births is $7.6 \%$.

It is also clear from the figure that the south region of India has the highest C-section rate, which is around 37\% followed by west region (20\%) and the north region (15\%). The central, east and north-east regions of India shows the C-section rates below the WHO specified 15\% mark. The percentage of emergency C-section births is also high in south region (14.4\%) followed by west region $(8.4 \%)$ and north region $(6.5 \%)$.

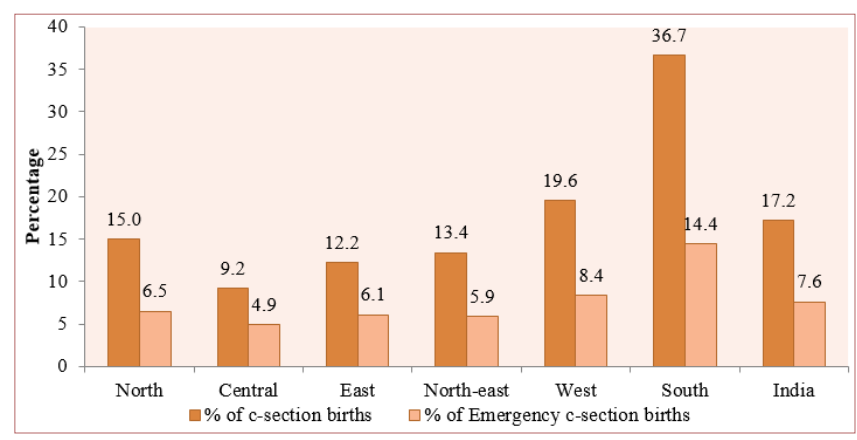

Figure I.Percentage of births delivered by C-section and emergency C-section births in India and its regions, NFHS-IV, 2015 - 16

Table 1, shows the percentage of C-section births and emergency $\mathrm{C}$-section births for each state and union territories of India. The percentage of C-section births vary from $5.8 \%$ in Nagaland to $57.7 \%$ in Telangana. In southern region, Telangana has the highest C-section rate of $57.7 \%$ followed by Andhra Pradesh with $40.1 \%$. Among the states/UTs in western region, Goa has the highest percentage of births delivered by C-section (31.4\%) followed by Maharashtra and Gujarat with C-section rate of 20.1 and 18.4 respectively. It is also clear 
from the table that in northern region, Jammu \& Kashmir, Delhi, Punjab and Chandigarh have the higher percentage of births delivered by C-section whereas Rajasthan, Haryana and Uttarakhand have the lower percentage of $\mathrm{C}$-section births. In India $7.6 \%$ of births were delivered by emergency C-section, which is $44 \%$ of total C-section births. It means that more than half of the total C-section births (56\%) were planned before onset of labour pains.

Table I.Percentage of births delivered by caesarean section and emergency C-section births out of total C-section births by regions (states/ UTs), India, NFHS-IV, 2015-16

\begin{tabular}{|c|c|c|c|}
\hline $\begin{array}{l}\text { Regions with } \\
\text { States/ UTs }\end{array}$ & $\begin{array}{l}\text { Perce- } \\
\text { ntage of } \\
\text { births } \\
\text { delivered } \\
\text { by } \\
\text { C-section }\end{array}$ & $\begin{array}{l}\text { Percentage } \\
\text { of births } \\
\text { delivered } \\
\text { by C-section } \\
\text { that was } \\
\text { planned after } \\
\text { onset of } \\
\text { labour pains } \\
\text { (Emergency } \\
\text { C-section } \\
\text { births) }\end{array}$ & $\begin{array}{c}\text { Perce- } \\
\text { ntage of } \\
\text { emergency } \\
\text { C-section } \\
\text { births out } \\
\text { of total } \\
\text { C-section } \\
\text { births }\end{array}$ \\
\hline \multicolumn{4}{|l|}{ North } \\
\hline Chandigarh & 22.6 & 8.7 & 38.5 \\
\hline Delhi & 26.7 & 10.5 & 39.3 \\
\hline Haryana & 11.7 & 5.8 & 49.6 \\
\hline $\begin{array}{l}\text { Himachal } \\
\text { Pradesh }\end{array}$ & 16.7 & 7.3 & 43.7 \\
\hline $\begin{array}{c}\text { Jammu \& } \\
\text { Kashmir }\end{array}$ & 33.1 & 10.8 & 32.6 \\
\hline Punjab & 24.6 & 11.1 & 45.1 \\
\hline Rajasthan & 8.6 & 4.0 & 46.5 \\
\hline Uttarakhand & 13.1 & 5.9 & 45.0 \\
\hline \multicolumn{4}{|l|}{ Central } \\
\hline Chhattisgarh & 9.9 & 5.4 & 54.5 \\
\hline $\begin{array}{l}\text { Madhya } \\
\text { Pradesh }\end{array}$ & 8.6 & 3.8 & 44.2 \\
\hline Uttar Pradesh & 9.4 & 5.2 & 55.3 \\
\hline \multicolumn{4}{|l|}{ East } \\
\hline Bihar & 6.2 & 3.7 & 59.7 \\
\hline Jharkhand & 9.9 & 5.5 & 55.6 \\
\hline Odisha & 13.8 & 7.3 & 52.9 \\
\hline West Bengal & 23.8 & 10.5 & 44.1 \\
\hline \multicolumn{4}{|l|}{ North-east } \\
\hline $\begin{array}{l}\text { Arunachal } \\
\text { Pradesh }\end{array}$ & 8.9 & 3.3 & 37.1 \\
\hline
\end{tabular}

\begin{tabular}{|c|c|c|c|}
\hline Assam & 13.4 & 6.3 & 47.0 \\
\hline Manipur & 21.1 & 8.0 & 37.9 \\
\hline Meghalaya & 7.6 & 2.3 & 30.3 \\
\hline Mizoram & 12.7 & 3.1 & 24.4 \\
\hline Nagaland & 5.8 & 2.9 & 50.0 \\
\hline Sikkim & 20.9 & 5.6 & 26.8 \\
\hline Tripura & 20.5 & 8.5 & 41.5 \\
\hline West & & & \\
\hline $\begin{array}{c}\text { Dadar \& } \\
\text { Nagar Haveli }\end{array}$ & 16.2 & 4.9 & 30.2 \\
\hline Daman \& Diu & 15.7 & 7.0 & 44.6 \\
\hline Goa & 31.4 & 15.0 & 47.8 \\
\hline Gujarat & 18.4 & 8.9 & 48.4 \\
\hline Maharashtra & 20.1 & 8.2 & 40.8 \\
\hline South & & & \\
\hline A \& N Islands & 19.3 & 8.6 & 44.6 \\
\hline $\begin{array}{c}\text { Andhra } \\
\text { Pradesh }\end{array}$ & 40.1 & 14.4 & 35.9 \\
\hline Karnataka & 23.6 & 10.4 & 44.1 \\
\hline Kerala & 35.8 & 12.8 & 35.8 \\
\hline Lakshadweep & 38.4 & 11.8 & 30.7 \\
\hline Pondicherry & 33.6 & 12.1 & 36.0 \\
\hline Tamilnadu & 34.1 & 13.2 & 38.7 \\
\hline Telangana & 57.7 & 23.4 & 40.6 \\
\hline India & 17.2 & 7.6 & 44.2 \\
\hline
\end{tabular}

\section{Differentials in $\mathrm{C}$-section Births by Various Background Characteristics}

The combination of various socio-economic factors, risk factors, institutional and individual behavioural factors can determine the $\mathrm{C}$-section rate in the region. The percentage of $\mathrm{C}$-section births by various background characteristics in India and its regions has been shown in Table 2. The bivariate analysis reveals that the rate of $\mathrm{C}$-section in urban areas is much higher than rural areas in India and in its all regions. In India, the C-section rate in urban areas (28.2\%) is more than double than its counterparts (12.8\%). This disparity between rural and urban areas is maximum in north-east region (21.8 points) and minimum in southern region (7.3 points). It has also been noted that in southern region, the C-section rate even in rural areas $(33.6 \%)$ is more than doubled than the recommended rate of $15 \%$ by WHO. The other most important socio-economic factors for C-section delivery are mother's educational status and wealth quintile. There is a steady rise in percentage of women who have undergone C-section delivery with increasing educational status and wealth quintile. In India, 
the percentage of $\mathrm{C}$-section rate is very high among women having secondary and higher education and belonging to rich wealth quintile as compared to their counterparts. The same pattern has been observed in all regions. In southern region, around one-fourth of women (24\%) who have no education and belonging to poorest wealth quintile have undergone C-section delivery.

Table 2.Percentage of C-section births by various factors in India and its regions, NFHS-IV, 20I5-16

\begin{tabular}{|c|c|c|c|c|c|c|c|}
\hline \multirow{2}{*}{ Various Factors } & \multicolumn{7}{|c|}{ Percentage of births delivered by C-section } \\
\hline & North & North-east & East & West & Central & South & India \\
\hline \multicolumn{8}{|l|}{ Socio-economic factors } \\
\hline \multicolumn{8}{|l|}{ Place of residence } \\
\hline Rural & 11.4 & 10.3 & 9.5 & 14.1 & 6.5 & 33.6 & 12.8 \\
\hline Urban & 22.1 & 32.1 & 26.3 & 26.8 & 18.9 & 40.9 & 28.2 \\
\hline \multicolumn{8}{|l|}{ Educational status } \\
\hline No education & 6.8 & 2.9 & 3.9 & 6.4 & 3.9 & 24.1 & 6.0 \\
\hline Primary & 11.6 & 5.8 & 9.2 & 11.4 & 6.1 & 32.9 & 11.5 \\
\hline Secondary & 18.1 & 16.6 & 18.2 & 20.2 & 11.9 & 36.3 & 21.4 \\
\hline Higher & 28.4 & 47.2 & 43.1 & 41.7 & 27.4 & 48.5 & 38.6 \\
\hline \multicolumn{8}{|l|}{ Wealth Quintile } \\
\hline Poorest & 2.9 & 3.1 & 4.5 & 5.4 & 2.8 & 23.9 & 4.4 \\
\hline Poorer & 5.7 & 7.5 & 9.8 & 8.2 & 5.2 & 25.2 & 9.7 \\
\hline Middle & 11.9 & 17.6 & 18.6 & 14.9 & 9.6 & 34.1 & 19.0 \\
\hline Richer & 15.1 & 34.8 & 31.7 & 24.0 & 14.5 & 40.2 & 26.8 \\
\hline Richest & 26.7 & 50.2 & 51.8 & 36.2 & 29.1 & 46.4 & 35.9 \\
\hline \multicolumn{8}{|l|}{ Religion } \\
\hline Hindu & 13.2 & 20.5 & 12.6 & 19.8 & 9.0 & 37.2 & 17.3 \\
\hline Muslim & 17.8 & 6.1 & 11.2 & 17.7 & 9.8 & 32.8 & 15.1 \\
\hline Christian & 27.7 & 8.6 & 5.7 & 32.0 & 10.6 & 39.0 & 24.8 \\
\hline Others & 25.2 & 12.6 & 10.5 & 19.8 & 33.7 & 28.6 & 20.5 \\
\hline \multicolumn{8}{|l|}{ Caste/ Tribe } \\
\hline Scheduled Caste & 12.9 & 18.8 & 10.7 & 17.7 & 6.3 & 31.3 & 14.5 \\
\hline Scheduled Tribe & 5.7 & 9.7 & 5.4 & 9.6 & 3.0 & 29.3 & 8.3 \\
\hline $\mathrm{OBC}$ & 11.4 & 17.7 & 8.9 & 21.6 & 9.0 & 38.2 & 17.2 \\
\hline Others & 21.5 & 16.5 & 22.0 & 23.2 & 18.4 & 46.8 & 23.7 \\
\hline \multicolumn{8}{|l|}{ Currently working } \\
\hline No & 16.8 & 14.9 & 13.0 & 21.6 & 10.1 & 38.6 & 19.0 \\
\hline Yes & 14.0 & 13.9 & 6.4 & 13.5 & 6.7 & 36.6 & 15.7 \\
\hline \multicolumn{8}{|l|}{ Risk Factors } \\
\hline \multicolumn{8}{|l|}{ Mother's age at birth } \\
\hline$<25$ & 12.1 & 10.8 & 12.3 & 15.9 & 8.8 & 34.2 & 16.1 \\
\hline $25-34$ & 18.4 & 16.3 & 12.5 & 23.7 & 10.0 & 40.2 & 18.9 \\
\hline $35+$ & 19.3 & 14.4 & 6.4 & 32.8 & 6.7 & 45.3 & 14.4 \\
\hline \multicolumn{8}{|l|}{ Birth Order } \\
\hline 1 & 20.0 & 20.6 & 20.0 & 25.1 & 14.4 & 40.0 & 23.8 \\
\hline 2 & 16.0 & 13.3 & 12.1 & 19.1 & 10.2 & 38.0 & 18.9 \\
\hline
\end{tabular}


Kathuria B et al.

\begin{tabular}{|c|c|c|c|c|c|c|c|}
\hline $3+$ & 7.1 & 4.2 & 3.9 & 9.9 & 4.1 & 22.3 & 6.6 \\
\hline \multicolumn{8}{|l|}{ Multiple Births } \\
\hline Single Birth & 14.8 & 13.4 & 12.1 & 19.3 & 9.1 & 36.2 & 16.9 \\
\hline Multiple Births & 29.4 & 14.8 & 19.4 & 39.0 & 18.7 & 61.6 & 30.5 \\
\hline \multicolumn{8}{|l|}{ Any Pregnancy Complication } \\
\hline No & 12.6 & 11.9 & 9.7 & 17.6 & 7.4 & 38.3 & 13.9 \\
\hline Yes & 20.0 & 17.5 & 20.2 & 23.9 & 15.2 & 38.1 & 23.8 \\
\hline \multicolumn{8}{|l|}{ Size of child at birth } \\
\hline Larger than Average & 17.2 & 18.9 & 16.0 & 19.6 & 11.9 & 38.4 & 22.1 \\
\hline Average & 14.9 & 13.4 & 11.7 & 20.1 & 8.8 & 36.1 & 16.4 \\
\hline Smaller than Average & 15.2 & 13.4 & 10.5 & 18.0 & 9.6 & 37.3 & 15.3 \\
\hline \multicolumn{8}{|l|}{ Weight of Child at Birth } \\
\hline$<3 \mathrm{Kg}$ & 17.6 & 17.3 & 16.6 & 19.8 & 13.0 & 35.7 & 20.5 \\
\hline $3+\mathrm{Kg}$ & 17.5 & 18.6 & 16.2 & 21.5 & 13.4 & 39.1 & 22.1 \\
\hline \multicolumn{8}{|l|}{ BMI of Respondent } \\
\hline$<18.5$ & 9.2 & 8.9 & 7.3 & 13.0 & 5.7 & 29.3 & 11.0 \\
\hline $18.5-24.9$ & 12.6 & 12.2 & 11.5 & 18.3 & 8.2 & 33.0 & 15.1 \\
\hline $25-29.9$ & 29.2 & 29.3 & 29.9 & 31.8 & 19.9 & 48.7 & 33.2 \\
\hline $30+$ & 41.6 & 41.8 & 39.9 & 41.7 & 32.9 & 57.8 & 45.2 \\
\hline \multicolumn{8}{|c|}{ Institutional and Individual Behavioural Factors } \\
\hline \multicolumn{8}{|l|}{ No. of ANC Visits } \\
\hline None & 6.5 & 4.5 & 4.8 & 11.3 & 3.2 & 27.0 & 6.4 \\
\hline $1-3$ & 11.3 & 10.2 & 9.3 & 16.2 & 8.0 & 36.2 & 12.1 \\
\hline $4+$ & 23.6 & 21.9 & 24.6 & 24.1 & 19.4 & 39.6 & 27.7 \\
\hline \multicolumn{8}{|l|}{ Place of Delivery } \\
\hline Public & 12.6 & 13.6 & 8.9 & 12.5 & 5.1 & 25.3 & 11.9 \\
\hline NGO & 40.0 & 18.8 & 40.1 & 33.7 & 28.6 & 46.1 & 35.8 \\
\hline Private & 31.3 & 51.2 & 45.8 & 30.5 & 33.8 & 54.2 & 41.0 \\
\hline \multicolumn{8}{|l|}{ Access to Mass Media } \\
\hline Not at all & 4.7 & 4.1 & 4.4 & 8.0 & 3.6 & 24.2 & 5.0 \\
\hline Less than once a week & 8.2 & 6.8 & 8.2 & 13.0 & 6.0 & 28.1 & 8.8 \\
\hline At least once a week & 13.0 & 12.2 & 11.2 & 15.1 & 8.3 & 32.3 & 13.0 \\
\hline Almost every day & 19.1 & 24.3 & 23.1 & 23.5 & 15.3 & 37.8 & 25.3 \\
\hline \multicolumn{8}{|c|}{ Access to Media on Public Health Issues } \\
\hline No & 8.3 & 6.5 & 7.1 & 13.6 & 4.7 & 31.7 & 9.7 \\
\hline Yes & 18.4 & 19.8 & 18.7 & 22.8 & 13.2 & 38.2 & 22.5 \\
\hline
\end{tabular}

The percentage of $\mathrm{C}$-section rate is higher among women in age group of 25-34 years as compared to those women who are either younger or older from this age group $(<25$ years or $35+$ years). The $\mathrm{C}$-section rate is much higher among women having multiple births and having child for the first time. The percentage of C-section births is also higher among women who had any complications during pregnancy as compared to those who did not had pregnancy complications in India and in its all regions except in southern region (Table 2). Another important factors for C-section delivery are size of child at birth and weight of child at birth. The child having larger size at time of birth and child with weight of more than $3 \mathrm{~kg}$ at birth are at high risk of being delivered by $\mathrm{C}$-section. It has also been noted 
that the percentage of births delivered by C-section is much higher among obese women as compared to thin women.

It has been reveal from the Table 2 that the percentage of $\mathrm{C}$-section rate is much higher among women who had more than 4 ANC visits as compared to those who did not have any ANC visit. The place of delivery is also one of the most important factors responsible for delivery outcome. In India, the percentage of women who have undergone C-section in private institutions (41\%) is more than three times compared to $\mathrm{C}$-section in public institutions (11.9\%). The percentage of C-section births is much higher among women who had access to mass media almost every day and access media on public health issues as compared to those women who did not access at all.

\section{Determinants of C-section Births in India}

Table 3.Logistic regression model showing the effects of various associated factors on $\mathrm{C}$-section rates in India, NFHS-IV, 2015-16

\begin{tabular}{|c|c|c|}
\hline Various Factors & Odds Ratio & p-value \\
\hline \multicolumn{3}{|l|}{ Place of residence } \\
\hline \multicolumn{3}{|l|}{ Rural $^{\circledR}$} \\
\hline Urban & 1.264 & 0.000 \\
\hline \multicolumn{3}{|l|}{ Educational status } \\
\hline \multicolumn{3}{|l|}{ No education ${ }^{\circledR}$} \\
\hline Primary & 1.373 & 0.000 \\
\hline Secondary & 1.802 & 0.000 \\
\hline Higher & 2.643 & 0.000 \\
\hline \multicolumn{3}{|l|}{ Wealth Index } \\
\hline \multicolumn{3}{|l|}{ Poorest ${ }^{\circledR}$} \\
\hline Poorer & 1.754 & 0.000 \\
\hline Middle & 3.517 & 0.000 \\
\hline Richer & 4.676 & 0.000 \\
\hline Richest & 5.309 & 0.000 \\
\hline \multicolumn{3}{|l|}{ Religion } \\
\hline \multicolumn{3}{|l|}{ Hindu ${ }^{\circledR}$} \\
\hline Muslim & 0.685 & 0.000 \\
\hline Christian & 1.223 & 0.039 \\
\hline Others & 1.112 & 0.264 \\
\hline \multicolumn{3}{|l|}{ Caste/ Tribe } \\
\hline \multicolumn{3}{|l|}{ Scheduled Caste ${ }^{\circledR}$} \\
\hline Scheduled Tribe & 0.712 & 0.000 \\
\hline $\mathrm{OBC}$ & 1.040 & 0.382 \\
\hline General & 1.062 & 0.238 \\
\hline \multicolumn{3}{|l|}{ Currently working } \\
\hline $\mathrm{No}{ }^{\circledR}$ & & \\
\hline
\end{tabular}

\begin{tabular}{|c|c|c|}
\hline Yes & 0.926 & 0.090 \\
\hline \multicolumn{3}{|c|}{ Risk factors } \\
\hline \multicolumn{3}{|l|}{ Mother's age at birth } \\
\hline \multicolumn{3}{|l|}{$<25^{\circledR}$} \\
\hline $25-34$ & 1.445 & 0.000 \\
\hline $35+$ & 2.553 & 0.000 \\
\hline \multicolumn{3}{|l|}{ Birth Order } \\
\hline \multicolumn{3}{|l|}{$1^{\circledR}$} \\
\hline 2 & 0.713 & 0.000 \\
\hline $3+$ & 0.339 & 0.000 \\
\hline \multicolumn{3}{|l|}{ Multiple Births } \\
\hline \multicolumn{3}{|l|}{ Single Birth ${ }^{\circledR}$} \\
\hline Multiple Births & 3.010 & 0.000 \\
\hline \multicolumn{3}{|l|}{$\begin{array}{c}\text { Any Pregnancy } \\
\text { Complication }\end{array}$} \\
\hline \multicolumn{3}{|l|}{$\mathrm{No}{ }^{\circledR}$} \\
\hline Yes & 1.001 & 0.981 \\
\hline \multicolumn{3}{|l|}{ Size of child at birth } \\
\hline \multicolumn{3}{|l|}{ Larger than Average ${ }^{\circledR}$} \\
\hline Average & 0.797 & 0.000 \\
\hline Smaller than Average & 0.875 & 0.052 \\
\hline \multicolumn{3}{|l|}{ Weight of Child at Birth } \\
\hline \multicolumn{3}{|l|}{$<3 \mathrm{Kg}^{\circledR}$} \\
\hline $3+\mathrm{Kg}$ & 0.994 & 0.864 \\
\hline \multicolumn{3}{|l|}{ BMI of Respondent } \\
\hline \multicolumn{3}{|l|}{$<18.5^{\circledR}$} \\
\hline $18.5-24.9$ & 1.248 & 0.000 \\
\hline $25-29.9$ & 1.976 & 0.000 \\
\hline $30+$ & 2.338 & 0.000 \\
\hline \multicolumn{3}{|c|}{ Institutional and Individual Behavioural Factors } \\
\hline \multicolumn{3}{|l|}{ No. of ANC Visits } \\
\hline \multicolumn{3}{|l|}{ None ${ }^{\circledR}$} \\
\hline $1-3$ & 1.054 & 0.522 \\
\hline $4+$ & 1.536 & 0.000 \\
\hline \multicolumn{3}{|l|}{ Place of Delivery } \\
\hline \multicolumn{3}{|l|}{ Public ${ }^{\circledR}$} \\
\hline NGO & 4.177 & 0.000 \\
\hline Private & 3.792 & 0.000 \\
\hline \multicolumn{3}{|l|}{ Access to Mass Media } \\
\hline \multicolumn{3}{|l|}{ Not at all ${ }^{\circledR}$} \\
\hline Less than once a week & 0.956 & 0.659 \\
\hline At least once a week & 1.017 & 0.850 \\
\hline
\end{tabular}




\begin{tabular}{|c|c|c|}
\hline Almost every day & 1.054 & 0.480 \\
\hline $\begin{array}{c}\text { Access to Media on Public } \\
\text { Health Issues }\end{array}$ & & \\
\hline No $^{\circledR}$ & & \\
\hline Yes & 1.094 & 0.051 \\
\hline Region & & \\
\hline North ${ }^{\circledR}$ & & \\
\hline North-east & 0.544 & 0.000 \\
\hline East & 0.551 & 0.000 \\
\hline West & 0.772 & 0.023 \\
\hline Central & 0.400 & 0.000 \\
\hline South & 1.318 & 0.013 \\
\hline Note: ${ }^{\circledR}$ Reference Category & & \\
\hline
\end{tabular}

To examine the net effect of background variables on $\mathrm{C}$-section deliveries in India, a logistic regression has been applied (Table 3). The logistic regression analysis reveals that all the socio-economic factors show significant impact on $\mathrm{C}$-section except the factor currently working. The results also shows that C-section delivery has statistically significant effect on place of residence, wealth index, religion, mother's age, birth order, multiple births, size of child at birth, BMI, no. of ANC visit, place of delivery and region. C-section deliveries are more likely to occur in urban areas and among women from higher wealth quintile as compared to their counterparts. Similarly, C-section deliveries are significantly more likely to occur among women aged 25 or more and who had multiple births. The birth order is negatively related to the occurrence of C-section delivery. The children of higher order births are less likely to be delivered by C-section as compared to first order birth. Women who are obese and women who had taken more than 4 ANC visits are more likely to delivered births by C-section. Place of delivery is an important significant factor for C-section delivery. As compared to public institutions, deliveries in private institutions are more likely to be performed by C-section.

\section{Discussion}

The present study investigates the regional variation in the prevalence of caesarean section in India and its associated factors. The analysis showed that the rate of caesarean deliveries to the total births, has a huge variation between regions, $36.7 \%$ in southern region compared to $9.2 \%$ in central region out of total $17.2 \%$ in India. The central, east and north-east regions of India shows the C-section rates below the WHO specified $15 \%$ mark. The C-section rate is found much higher (28.2\%) in urban part of India, which is more than double than the rural part i.e., $12.8 \%$. Similar kinds of the disparity in rates of C-section among urban and rural women are also found in each region except

southern region. These high rates in urban areas may be due to the combination of several factors like, availability and accessibility of advanced health facilities, high levels of women's choice, and wide prevalence of private sector in health care for making profit. An analysis using DLHS-4 done by Singh $\mathrm{P}$ et al. found that high proportion of deliveries through caesarean section in urban areas $28.6 \%$ compared to $19.5 \%$ in rural areas in India. ${ }^{10}$ Our analysis further shows that the diffusion of caesarean is closely associated with socio-economic status.

Educational status of mother is another socio-economic factor related to the performance of $\mathrm{C}$-section deliveries. The analysis indicates that, the likelihood of C-section is more than two times higher among highly educated mothers compared to uneducated mothers $(O R=2.6)$. A study conducted at United Kingdom, found that higher education is associated with an increased rate of caesarean section. ${ }^{11}$ Similar kind of findings has been observed in another study conducted in rural south India, women acquiring education of graduation or above, the proportion of undergoing caesarean section delivery also increases. ${ }^{12,14}$ Two others works also depict that higher education is associated with greater incidence of C-section. ${ }^{13,15}$

Mothers with richest wealth index are more likely to undergone $\mathrm{C}$-section $(\mathrm{OR}=5.31$ ) compares to the women from poorest wealth group. Many researchers also proved that mothers belonging to higher socio-economic status have higher number of caesarean section. ${ }^{16,18,19}$ The finding of the study also supports the results of the other studies conducted in Asia and Africa. ${ }^{20}$ The reason may be explained that the people with higher socio-economic status usually choose private facility where C-section deliveries are common whereas, poorer household fails to pay for the surgery and extra costs associated with C-section.

The influence of risk factors on C-section deliveries indicates that the C-section deliveries are significantly more likely to occur among mothers with higher age, mothers having multiple births, mothers with pregnancy complications, large size of child at birth, weight of the child more than $3 \mathrm{~kg}$ and BMI. Several studies have indicated similar findings. ${ }^{13,14,17,18} \mathrm{~A}$ recent study conducted in Bangladesh and other developing countries stated that women's advanced maternal age are more likely to suffer from obstetric and maternal complications than women in middle age and this may subsequently contribute to the increasing $\mathrm{C}$-section delivery rate..$^{21,22}$ Institutional and individual behavioural factors are other significant factors which are contributing for the C-section deliveries. Several studies confirmed that the prevalence of caesarean deliveries is higher in private health facilities than public facilities. ${ }^{23-25}$ This study also found that women who had more than four ANCs are significantly more likely to have a C-section delivery. This 
may not because of the ANC that caesarean is more, but it may be because those who have more number of ANC visits may be more likely to have delivery related complications and hence large proportion of them might have gone for caesarean delivery. ${ }^{26}$

The regional analysis indicates that the $\mathrm{C}$-section deliveries are more likely to be in southern region compared to northern region. Study conducted in South India found that the highest caesarean rates were observed in southern states, notably in Telangana, Andhra Pradesh, and Kerala, as well as in most part of Karnataka and Tamil Nadu. ${ }^{27}$ The main reason for this transition is increase in institutional delivery increases the caesarean delivery rates in all southern states. This finding corroborates the findings of Srivastava S et al..$^{28}$

\section{Conclusion}

From this study, it can be concluded that, the C-section deliveries are significantly higher in southern region followed by western region in India. Increase in institutional deliveries may be an important reason for inclination of caesarean deliveries in southern region, much higher than WHO recommended standard of $15 \%$. The main reason for this high caesarean rate is that, it reduces the risks and complications occurred during the deliveries. The obtained findings also indicated that in the saving of life of children in India, caesarean performs better than normal deliveries. Social factors such as higher education of mother, residing in urban area, belong to richest wealth group, mothers belong to non-SC/ST category are more likely to opt for C-section delivery. Evidence also indicates that risk factors like high age of mother, high birth order, complicated pregnancy, multiple births, size of child at birth are significantly influences the decision of C-section deliveries. Institutional and individual behavioural factors such as number of ANC visits, place of delivery, access to mass media are also found to be significant determinants of opting C-section delivery. Place of delivery is a strongest predictor, influencing the $\mathrm{C}$-section delivery. It shows that the need for growth of health care delivery system and to encourage institutional deliveries in public sector in India. Delivering high quality timely care and counselling measures throughout the gestation period, is the responsibility of every midwife healthcare provider, as a measure to minimise C-section deliveries. There is an urgent need to monitor the deliveries in clinics and hospitals to find out the right balance between demand and provisioning of high quality health care services. The government should inform the practitioners and women of the unnecessary risks of non-medically justified C-sections.

\section{Acknowledgements: None}

\section{Funding: None \\ Conflicts of Interest: None}

\section{References}

1. Betran AP, Torloni MR, Zhang JJ et al. For the WHO Working Group on Caesarean Section. WHO statement on caesarean section rates: a commentary. BJOG, 2015.

2. World Health Organization. WHO Statement on Caesarean Section Rates, Department of Reproductive Health and Research, 2015. 2019. Available from: https:// apps.who.int/iris/bitstream/handle/10665/161442/ WHO_RHR_15.02_eng.pdf; jsessionid=E8750E7EFC1B4501D5B66BECB525A7CE?sequence=1.

3. Goer H. The thinking woman's guide to a better birth: Penguin; Tarcher Perigee. The Barkley Publishing Group Penguin Group (USA) Inc., New York. 1999.

4. Villar J, Valladares E, Wojdyla D et al. Caesarean delivery rates and pregnancy outcomes: the 2005 WHO global survey on maternal and perinatal health in Latin America. The Lancet 2006; 367(9525): 1819-29.

5. Mastaki JK. Social predictors of caesarean section births in Italy. Afr Health Sci 2011; 11(4): 560-5.

6. Khawaja M, Al-Nsour M, Khawaja M. Trends in prevalence and determinants of caesarean delivery in Jordan: Evidence from three demographic and health surveys 1990-2002. World Health and Population, 2007.

7. Gibbons L, Belizan JM, Lauer JA et al. Inequities in the use of cesarean section deliveries in the world. Am J Obstet Gynecol 2012; 206(4): 331.e1-19.

8. Betrán AP, Ye J, Moller AB et al. The increasing trend in cesarean section rates: global, regional and national estimates: 1990-2014. PLoS One 2016; 11(2): e0148343.

9. International Institute for Population Sciences and ICF. National Family Health Survey (NFHS-4), 2015-16. IIPS, Mumbai, India. 2017. Available from: https:// dhsprogram.com/pubs /pdf/FR339/FR330.pdf. 2019.

10. Singh P, Hashmi G, Swain PK. High prevalence of caesarean section births in private sector health facilities- analysis of district level household survey-4 (DLHS-4) of India. BMC Public Health 2018; 18: 613.

11. Gilbert A, Benjamin A, Abenhaim HA. Does education level influence the decision to undergo elective repeat caesarean section among women with a previous caesarean section? J Obstet Gynaecol Can 2010; 32(10): 942-7.

12. Divyamol N, Raphael L, Koshy N. Caesarean section rate and its determinants in a rural area of South India. Int. J Community Med Public Health 2016; 3: 2836-2840.

13. Amjad A, Amjad U, Zakar R et al. Factors associated with caesarean deliveries among child-bearing women in Pakistan: secondary analysis of data from the demographic and health survey, 2012-13. BMC Pregnancy and Childbirth 2018; 18: 113.

14. Ghosh S. Increasing trend in caesarean section delivery in India: role of medicalization of maternal health. The Institute for Social and Economic Change, Bangalore. 
2010.

15. Chacham AS, Perpetuo HO. The Incidence of Caesarean Deliveries in Belo Horizonte, Brazil: Social and Economic Determinants. Reproductive Health Matter 2010; 6(11): 115-21.

16. Padmadas SS, Kumar SS, Nair SB et al. Caesarean section delivery in Kerala, India: Evidence from a National Health Survey. Social Science and Medicine 2000; 51: 511-21.

17. Parikh U, Oza PR. Study of rate, trends and determinants of caesarean section among mothers attending a tertiary care center in Ahmedabad, Gujarat, India. Int J Intg Med Sci 2018; 5(2): 577-81.

18. Kaur, J, Singh S, Kaur K. Current trend of caesarean sections and vaginal births. Advances in Applied Science Research 2013; 4(4): 196-202.

19. Patel RV, Gosalia EV, Deliwala KJ et al. Indications and trends of caesarean birth delivery in the current practice scenario. Int J Reprod Contracept Obstet Gynecol 2014; 3(3): 575-80.

20. Cavallaro FL, Cresswell JA, França GV, et al. Trends in caesarean delivery by country and wealth quintile: cross-sectional surveys in southern Asia and subSaharan Africa. Bull World Health Organ 2013; 91(12): 914-22D.

21. Khan MN, Islam MM, Shariff AA et al. Socio-demographic predictors and average annual rates of caesarean section in Bangladesh between 2004 and 2014. PLoS One 2017; 11-12(5): e0177579.

22. Bayrampour $\mathrm{H}$, Heaman M. Advanced maternal age and the risk of cesarean birth: a systematic review. Birth 2010; 37(3): 219-26.

23. Neuman M, Alcock G, Azad K et al. Prevalence and determinants of caesarean section in private and public health facilities in underserved South Asian communities: cross-sectional analysis of data from Bangladesh, India and Nepal. BMJ Open 2014; 1-4(12): e005982.

24. Vieira GO, Fernandes LG, de Oliveira NF, et al. Factors associated with cesarean delivery in public and private hospitals in a city of northeastern Brazil: across-sectional study. BMC Pregnancy Childbirth 2015; 15(1): 132.

25. Maktha VK, Ghatam A, Padamata $\mathrm{H}$ et al. Prevalence and factors associated with caesarean section: a community based cross sectional study in rural parts of Rangareddy district, Telangana, India. International Journal of Community Medicine and Public Health 2017; 3(8): 2054-7.

26. Sing SK, Vishwakarma D, Sharma SK. Prevalence and determinants of voluntary caesarean deliveries and socioeconomic inequalities in India: Evidence from National Family Health Survey (2015-16). Clinical Epidemiology and Global Health 2020; 8: 335-42.
27. Guilmoto CZ, Dumont, A. Trends, regional variations, and socioeconomic disparities in cesarean births in India, 2010-2016. JAMA Network Open 2019; 2(3): e190526.

28. Srivastava S, Chaursaia H, Singh KHJK et al. Exploring the spatial patterns of cesarean section delivery in India: Evidence from National Family Health Survey-4. Clinical Epidemiology and Global Health 2020; 8: 414-22. 